\title{
THE ESL TEACHERS' WILLINGNESS TO COMMUNICATE IN ENGLISH
}

\author{
Yueh Yea Lo \\ University of Malaya, Malaysia \\ loyuehyea@gmail.com
}

First received: II October 2017

Final proof received: 30 January 2018

\begin{abstract}
Willingness to communicate (WTC) as introduced by McCroskey and Bear (1985) has developed and been perceived by many as a critical field. Unfortunately, there is a noticeable gap in research on the willingness to communicate (WTC) in English among ESL teachers in the Malaysian context. This study aims to investigate the ESL teachers' willingness to communicate in English in terms of gender and school locations. The four constructs of communication in WTC are group discussions, interpersonal, public, and talking in meetings. Through both criterion and convenience sampling, 250 ESL teachers from twenty-five schools were chosen for this research. Survey questionnaire with a total of 20 items adopted from McCroskey (1992) was used as the data collection instrument. Findings reveal that ESL teachers' willingness to communicate in English is generally high and that the teachers were more willing to converse and exchange ideas orally in English during the meeting rather than in group or public. Female participants were significantly different in their overall willingness to communicate as they were more willing to communicate in groups and public. The within-group comparison also shows that school locations (urban and rural) affect ESL teachers' willingness to communicate in English. The findings also suggest that schools should encourage more ESL teachers to participate in activities such as debates, drama, public speaking, English language clubs/society, and empower them by providing professional development workshops or training.
\end{abstract}

Keywords: willingness to communicate (WTC) in English; ESL teachers; school location; communication

The issues of low English communication proficiency and high expectations among ESL teachers and learners have been a major concern in the educational setting in many countries (Woodrow, 2006), which highlights the significance of discovering solutions to encourage and scaffold the level of oral communication among L2 users. In Malaysia, the notion of English language is believed to be the primary communication medium for knowledge transfer from primary to university level of education (Blueprint, Malaysian Education 20132025). In addition, the Malaysian Education Blueprint 2013-2025 have placed increasing emphasis on English communication, whereby a greater section of classroom and textbook activities has focused on face-to-face interaction, and various integrated communication programmes are conducted to raise awareness, and strengthen the link between performance and competencies (Blueprint, Malaysian Education 2013-2025). Despite the inevitable importance of English communication, there are still a large number of ESL teachers and learners who are afraid and reluctant to converse and exchange ideas in English outside the English lesson classroom owing to linguistic and pedagogy skills incompetence (Fern \& Jiar, 2012). Fatimawati (2012) also noted that this incompetence faced by both teachers and learners is the result of a decline in English language policy in Malaysia.
Individual differences are generally reviewed as essential in L2 communicative teaching and learning. Similarly, to improve communicative skills, one needs to use language (Yashima, ZenukNishide, \& Shimizu, 2004). Thus, the association between the concept of WTC in English and ESL teachers is potentially of great importance in the Malaysian ESL context and needs to be examined as a variable that affects communication outcomes. Gill's (2005) study on language policy in Malaysia found that there were limited opportunities for teachers and learners from urban to rural to use English outside the classroom. Hence, studies on identifying the ESL teachers' willingness to communicate in English from different school locations (rural and urban) are necessary. This study seeks to respond to this need. In particular, it aims to identify ESL teachers' willingness to communicate in English in terms of gender and school locations which have been underexplored in the extant literature.

By shedding light on understanding the effect of gender and school locations on the willingness to communicate (WTC) in English among ESL teachers, it is hoped that curriculum designers, policymakers, and school management board could help to improve communication in English at all levels starting from ESL teachers. Researchers in the field of ESL and professional teacher 
development may bridge the knowledge gap in the literature by using the findings from this study.

\section{Willingness to communicate (WTC) in ESL context}

Some of the pioneer studies on McCroskey and Bear's (1985) concept of willingness to communicate (WTC) were done by Burgoon (1976); Mortenson, Arnston, and Lustig, (1977); and McCroskey and Richmond (1982). McCroskey's communication motivation approach suggests that individuals have various reasons that encourage them to communicate or initiate communication such as (i) seeking affinity, (ii) seeking information, (iii) seeking decisions/consensus, (iv) confirming beliefs, and (v) expressing feelings. Moreover, Priest and Sawyer (1967) study proposed that proximity affects one's eagerness and readiness to converse and exchange ideas in English. For example, in their study, they found that school children were found to be more willing to communicate with their classmates next to them.

The notion of willingness to communicate (WTC) in English is believed to have a clear link with perceived self-esteem, and speaking opportunities to language acquisition (Pattapong, 2010; Skehan, 1989). Zheng and Zhou (2014) also pointed out that teacher quality, positive and effective use of English communication do indeed enhance learners' self-esteem, enthusiasm, and language development. For this reason, MacIntyre, Dornyei, Clement, and Noels (1998) noted that WTC is a key component of second language teaching. Emphasis on communicative competence is necessary for producing L2 users who are capable of communicating in the classroom, as well as outside the classroom.

In an attempt to explore elements that may potentially influence ESL teachers' willingness to communicate in English, this study will consider factors affecting ESL teachers' willingness to communicate in English in terms of (i) gender and (ii) school locations. The impact of gender and school locations on ESL teachers' willingness to communicate in English has not been investigated in previous studies. However, the extant literature on students' gender and type of study towards willingness to communicate provides inconsistent results (Alavania \& Alikhani, 2014; Arshad, Shahbaz, \& Al-Bashabsheh, 2015). Thus, it is important to know if there are significant differences in gender and school locations when it comes to ESL teachers' willingness to communicate in English and this information can be helpful in the future. Thus, at present, there is a noticeable gap in research on the willingness to communicate (WTC) in English among ESL teachers in the Malaysian context. The ESL teachers' willingness to communicate in English has not yet been studied thoroughly on its own within the Malaysian context, as most studies have paid attention to learners' and teacher trainees willingness to communicate in English (Fahim \& Dhamotharan, 2016; Yousef, Jamal, \& Razak, 2013). Thus, this study aims to delve into the relationship between ESL teachers' willingness to communicate (WTC) in English in terms of gender and school locations because inspiring and informed teacher is the most important school-related factor influencing students' achievement.

\section{Studies on willingness to communicate (WTC) in English in other countries}

Ghonsooly, Khajavy, and Asadpour (2012) conducted a study using WTC and socio-educational model to investigate 158 Iranian non-English major undergraduates' willingness to communicate in English, and the relationship among L2 learning and L2 communication variables (perceived communication competence, communication anxiety, attitude toward international community, interest in international activities, interest in foreign affairs, personality, and motivation). From their study, they found no significant differences between variables, except for communication anxiety and motivation. These findings were related to McCroskey's (2006) work and this means that communication motivation may encourage them to converse or initiate a conversation such as motivation to learn or acquire information.

A more recent study was carried out by Lahuerta (2014) in the Spanish higher education context. His study attempted to determine the factors affecting willingness to communicate (WTC) in English in a Spanish university. The results indicate that the undergraduates feel more comfortable and competent when communicating with group or friends in English, rather than in public and meetings. He also found that the level of motivation, communication anxiety, and selfperceived communication competence was viewed as factors that influence students' willingness to communicate in English. The study is limited in generalizing the findings because the target students' population in this study were all from one university, with 195 students majoring in Chemistry, Geography, Musicology, Art History, Finance and Accountancy, Tourism, Computing, and Industrial Engineering. In addition, the variables tested were based on four communication contexts; public speaking, talking in meetings, talking in small groups, and talking in dyads (strangers, acquaintances, and friends) adopted from McCroskey (1992).

\section{Studies on willingness to communicate (WTC) in English in Malaysia}

Yousef et al. (2013) conducted a study on Malaysian teacher trainees' willingness to communicate (WTC) in English at one of the local teacher training 
institutions. From his study, Weaver's (2005) and Gardner and Lambert's (1972) questionnaire was used to measure their willingness to communicate (WTC) and motivation aspect of learning English. In their study, they found that language learning communication strategies directly affect motivation, WTC, and communication confidence.

In addition, a more recent study was carried out to investigate the 230 teacher trainees' willingness to communicate in English within a faculty (Fahim \& Dhamotharan, 2016). The variables tested were adopted from McCroskey's (1992) four constructs of communication - group discussions, interpersonal, public, and talking in the meeting. Their study findings indicate that all the four variables and constructs of communication especially talking in meetings were significantly correlated with teacher trainees' WTC in English except those who have spent three years at the university. The results reveal that they were the most unwilling to communicate with a stranger and public speaking.

To sum up, most of the aforementioned studies focus on determining the types, conceptualisation, impact of WTC construct, and its measurement or factors loadings of WTC in English (e.g., communication anxiety in English, perceived communication competence in English) and students' (high school, undergraduate, trainee teachers) willingness to communicate (WTC) in English in a school, department, faculty, or university (Lahuerta, 2014; Mwalongo, 2016; Peng, 2007; Wen \& Clement, 2003; Yashima, 2002; Yousef et al., 2013). These past studies also did not provide an understanding of the willingness to communicate (WTC) in English among the ESL teachers in the Malaysian contexts. In other words, no study has been conducted to explore if there are differences of willingness to communicate (WTC) in terms of gender and school location (urban and rural) among Malaysian ESL teachers. Therefore, this study would help us understand and illuminate on these important issues.

Reflecting on the literature and the objectives of the study, the present study seeks to address the following research questions: (i) What is the effect of gender and school locations on the willingness to communicate (WTC) in English among ESL teachers in Malaysia?; and (ii) Are there any significant differences among the ESL teachers' willingness to communicate (WTC) in English in terms of their gender and school locations?

\section{METHOD}

\section{Research Design}

The research design of this study was a quantitative survey. The instrument was a closed-ended questionnaire, adapted from McCroskey (1992). There are two parts in the questionnaire - Part A with 2 demographic items and Part B with 20 items on a five-point Likert Scale. These 20 items measure four constructs of communication in WTC namely group discussions, interpersonal, public, and talking in the meeting.

\section{Participants}

Target participants were all ESL teachers in Johor, Malaysia. Through both criterion and convenience sampling, 250 ESL teachers from twenty-five schools were chosen for this research. The criteria for sampling were geographical proximity (Johor) and possession of certain key characteristics that are related to the purpose of this study (e.g., ESL teachers).

\section{Research Procedure}

The present study was carried out among the ESL teachers from twenty-five schools in Johor, Malaysia. Permission from relevant gatekeepers was obtained and the final version of the questionnaire was personally delivered and distributed to the ESL teachers in the twenty-five schools located in Johor, Malaysia. A total of 320 questionnaires were distributed to twenty-five schools in Johor and out of 320 questionnaires, 250 (78.13\%) ESL teachers' responses were collected over a period of one month.

\section{Research Instrument}

The instrument used in this study is the Willingness to Communicate in English: The ESL Teachers Context questionnaire. A twenty-item scaled designed by McCroskey (1992) with a Cronbach's $\alpha$ $=.91$ was used. The questionnaire has incorporated two parts; Part A (independent variables) and Part B (dependent variables) (see Table 1). The demographic information in part A was gathered to get a better perspective about them. ESL teachers were asked about their gender, and school locations.

Table 1. Variables on the willingness to communicate in English questionnaire

\begin{tabular}{cl}
\hline Part & Variables \\
\hline A & Independent Variables \\
& Gender \\
& School locations \\
B & Dependent Variables \\
& Group discussions \\
& Interpersonal \\
& Public \\
& Talking in meeting \\
\hline
\end{tabular}

In this study, four constructs of communication -group discussions, interpersonal, public, and talking in meeting with a total of 20 items in Part B (see Table 2) and these items were adapted from McCroskey (1992) regarding ESL teachers' willingness to communicate (WTC) in English. 
Table 2. Constructs and items

\begin{tabular}{ll}
\hline Constructs & Questionnaire Item No. \\
\hline Group discussions & $1,5,9,13,17$ \\
Interpersonal & $2,6,10,14,18$ \\
Public & $3,7,11,15,19$ \\
Talking in meeting & $4,8,12,16,20$ \\
\hline
\end{tabular}

Likert Scales was used in Part B of the questionnaire, comprising five responses namely no confidence, slight confidence, moderate confidence, high confidence, and very high confidence. Participants were asked to choose one of the five. The five responses range from "no confidence" to "very high confidence" with values $1-5$ on each item for scoring purposes (see Table 3).

Table 3. Scoring procedures

\begin{tabular}{lc}
\hline Scale & Value \\
\hline No Confidence & 1 \\
Slight Confidence & 2 \\
Moderate Confidence & 3 \\
High Confidence & 4 \\
Very High Confidence & 5 \\
\hline
\end{tabular}

\section{Instrument Design Issues \\ Validity}

Kaiser's (1974) Measure of Sampling Adequacy (KMO) was used to measure and make sure that the Willingness to Communicate in English: The ESL Teachers WTC questionnaire. The factor analysis was 0.87 and $p$-value was $(\mathrm{p}=<0.01)$.

\section{Reliability}

Cronbach's alpha was used to check the reliability of each variable. The ESL Teachers' WTC questionnaire Cronbach's alpha was 0.87. Based on table 4, the Cronbach's alpha coefficient value .87 (>.65) shows that it is a highly reliable instrument.

More information about participants and schools The participants of this study were ESL teachers from twenty-five schools in Johor, Malaysia. All the participants were ESL (English as a second language) teachers. The twenty-five schools in Johor were selected because their locations have relatively large numbers schools and teachers. Furthermore, these twenty-five schools represented two typical location representations - rural and urban schools in Malaysia of which the findings would be more representative.

Table 4. Reliability of the attitude and motivation instrument

\begin{tabular}{cc}
\hline No. of Items & Cronbach's Alpha \\
\hline 20 & .87 \\
\hline
\end{tabular}

\section{Methods of data analysis}

The closed-ended questionnaires yielded quantitative data which were analysed holistically using Statistical Product and Service Solutions (SPSS) version 23.0. The method of data analysis used in this study includes (i) descriptive statistics and (ii) inferential statistics. Detailed discussions are given in the following sections. The level of significance was set at the five percent level.

Descriptive statistics. The descriptive statistics used in this study were mean, frequency, percentages, and standard deviation, given that they reveal central tendencies among the target population (Ransirini, 2006). As presented in the research instrument section (see table 3), the values assigned for the Likert Scale range from 1 to 5 . The mean of the sum of the five-point Likert Scale is 3, which means, if the calculated mean is higher than 3 , then it shows a positive response. In other words, the higher the mean value obtained, the more positive the response.

Inferential statistics. The inferential statistics used in this study were sets of independent t-test (2tailed). Independent $\mathrm{t}$-tests were performed to analyse if there are any differences in willingness to communicate (WTC) in English between gender (males and females) and school locations (urban and rural). Table 5 below lists the research objectives, research questions, hypotheses (where applicable), and types of data analysis for this study.

\section{FINDINGS AND DISCUSSION}

The willingness to communicate (WTC) in English among ESL teachers in Malaysia

In order to find out the willingness to communicate (WTC) in English of ESL teachers, a survey was carried out. Data from the close-ended questionnaire in part B were analysed in four constructs of communication - group discussions, interpersonal, public, and talking in the meeting. The next section will present the overall findings for the four constructs of communication in WTC (see Table 6). Overall findings of the four constructs of communication. Table 6 below presents the overall findings for the four constructs of communication in WTC.

As shown in Table 6, a total of 250 ESL teachers participated in this study and there are 4 sub-constructs of communication namely (i) group discussions, (ii) interpersonal, (iii) public speaking, and (iv) talking in the meeting. The results of overall willingness to communicate (WTC) in English showed that ESL teachers were above moderate in their willingness to communicate in English $(\mathrm{M}=67.84, \mathrm{SD}=24.31)$. Malaysia ESL teachers' scores for willingness to communicate in the meeting $(\mathrm{M}=76.09, \mathrm{SD}=34.65)$ are considered high compared to the norm developed by McCroskey (1992), (>80 for high and $<39$ for low). 206 participants $(82.4 \%)$ said they were willing to communicate in the meeting while only 44 participants (17.6\%) showed low willingness to communicate in the meeting. This high score showed by Malaysia ESL teachers implies that it is 
very likely that most Malaysian ESL teachers have various reasons such as seeking affinity, information, and consensus that encourage them to converse or exchange ideas verbally in a meeting
(McCroskey, 2006). Thus, it is not surprising that Malaysia ESL teachers' scores for willingness to communicate in the meeting are high.

Table 5. Types of data and analysis

\begin{tabular}{|c|c|c|c|c|}
\hline No. & Research Objectives & Research Questions & Hypotheses & $\begin{array}{l}\text { Data } \\
\text { Analysis }\end{array}$ \\
\hline 1. & $\begin{array}{l}\text { To measure the } \\
\text { Malaysian ESL } \\
\text { teachers' willingness } \\
\text { to communicate } \\
\text { (WTC) in English. }\end{array}$ & $\begin{array}{l}\text { What is the willingness to } \\
\text { communicate (WTC) in } \\
\text { English among ESL } \\
\text { teachers in Malaysia? }\end{array}$ & $\begin{array}{l}\text { WTC in English vs. Gender } \\
\mathrm{H}_{0=} \text { There are no significant differences on } \\
\text { WTC in English between males and females' } \\
\text { when significant } p \text {-value is }>.05 \text {. } \\
\mathrm{H}_{1}=\text { There are significant differences on } \\
\text { WTC in English between males and females' } \\
\text { when significant } p \text {-value is }<.05 \text {. }\end{array}$ & $\begin{array}{l}\text { Descriptive } \\
\text { statistics } \\
\text { (mean, } \\
\text { standard } \\
\text { deviation, } \\
\text { and } \\
\text { percentages) }\end{array}$ \\
\hline
\end{tabular}

WTC in English vs. School locations

$\mathrm{H}_{0=}$ There are no significant differences on

WTC in English between urban and rural ESL teachers when significant $\mathrm{p}$-value is $>.05$.

$\mathrm{H}_{1}=$ There are significant differences on

WTC in English between urban and rural ESL teachers when significant $p$-value is $<.05$.

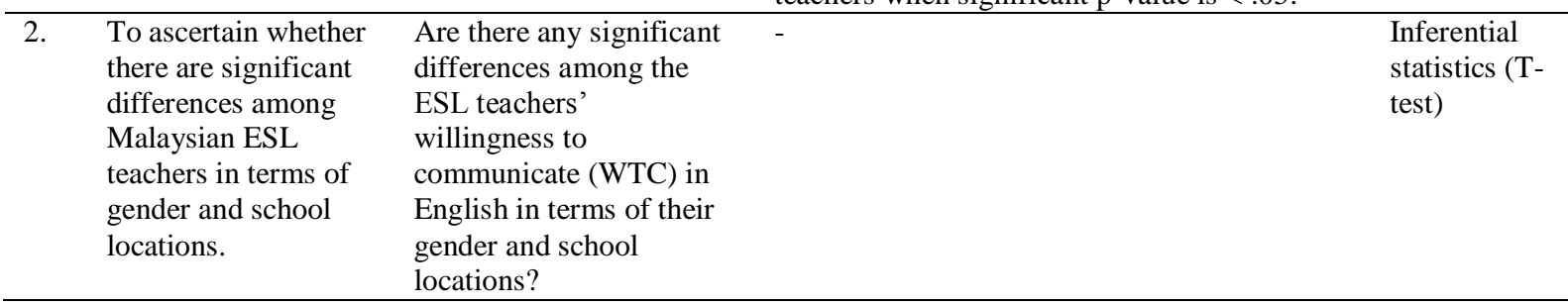

Table 6. Four constructs of communication in WTC

\begin{tabular}{|c|c|c|c|c|c|}
\hline \multirow[b]{2}{*}{ Sub-constructs of communication } & \multicolumn{2}{|c|}{ Current study } & \multirow[b]{2}{*}{ Std. Deviation (SD) } & \multicolumn{2}{|c|}{ Norm } \\
\hline & $\mathrm{N}$ & Mean (M) & & High & Low \\
\hline Overall WTC & 250 & 67.84 & 24.31 & $>82$ & $<52$ \\
\hline Group discussion & 250 & 72.09 & 33.65 & $>89$ & $<57$ \\
\hline Interpersonal & 250 & 56.28 & 22.34 & $>94$ & $<64$ \\
\hline Public speaking & 250 & 65.09 & 23.65 & $>78$ & $<22$ \\
\hline Talking in meeting & 250 & 76.09 & 34.65 & $>80$ & $<39$ \\
\hline
\end{tabular}

Based on Table 6, the scores for ESL teachers' interpersonal willingness to communicate are the lowest-noticeably eight points lower than $(<64)$ the average set by McCroskey $(\mathrm{M}=56.28, \mathrm{SD}=$ 22.34) compared to over 94 native speakers' high willingness to communicate with an individual. The suggested norm for interpersonal was $(>94=$ high, $<64=$ low $)$. The majority $(58 \%)$ of the participants showed low willingness to communicate in English and only a minority (42\%) of the participants showed moderate level. This low score may indicate that the level of an ESL teachers' interpersonal willingness to communicate (WTC) in English is closely linked, and affected by their own perceived self-esteem, and enthusiasm for language development. This finding also lends support to previous studies by Pattapong (2010) and Skehan (1989) where they found teachers interpersonal willingness to communicate (WTC) in English has a clear link with perceived self-esteem and speaking opportunities to language acquisition.
Moreover, the current study also showed that Malaysian ESL teachers were moderately high in the scores they gained when they were asked if they are competent and comfortable to speak English in a group discussion $(\mathrm{M}=72.09, \mathrm{SD}=33.65)$. The norm for group discussion is $(>89$ for high and $<57$ for low). This finding is coherent with Priest and Sawyer (1967). It reveals that proximity plays a great role in willingness to communicate (WTC).

Differences among the ESL teachers' willingness to communicate (WTC) in English in terms of gender and school locations

In order to find out if there are any significant differences among the ESL teachers' willingness to communicate (WTC) in English in terms of gender and school locations, a survey was carried out. Data from the close-ended questionnaire were analysed using a T-Test. 
Table 7. T-test for comparing the overall willingness to communicate in English of male and female ESL teachers

\begin{tabular}{|c|c|c|c|c|c|c|}
\hline & Gender & Mean & Std. dev. & $\mathrm{t}$ & df & p (sig.) \\
\hline \multirow{2}{*}{ Willingness to communicate in English } & Male & 3.54 & .24 & .32 & 198 & .65 \\
\hline & Female & 3.75 & .22 & .32 & 198 & .65 \\
\hline
\end{tabular}

Table 7 presents the overall comparison of male and female ESL teachers' willingness to communicate in English. The female ESL teachers' mean score of 3.75 is higher than that of the male counterparts, with a mean score of 3.54. This shows that female ESL teachers are more willing to communicate in English. For the case above, a t-test with a 2-tail probability was applied to find out whether there are overall differences between gender and willingness to communicate in English. Table 7 shows a p-value of $0.65(\alpha<0.01)$, which indicates that the variance for willingness to communicate in English between the two groups, male and female, is equal. As the $\mathrm{p}=0.65>0.05$, we do not reject the null hypothesis and conclude that there are no overall significant differences between willingness to communicate in English and gender. In other words, male and female ESL teachers had more or less the same level of willingness to communicate in English.

To be more precise, both male and female ESL teachers' scores were compared using a t-test with a p-value $<0.05$ in terms of the four constructs of communication namely (i) group discussion, (ii) interpersonal, (iii) public speaking, and (iv) talking in meeting to find out whether the differences between gender and each construct were significant or not (see Table 8).

Table 8. T-test for comparing all 4 constructs of communication between male and female ESL teachers

\begin{tabular}{llccccc}
\hline Constructs of communication & Gender & Mean & Std. dev. & $\mathrm{t}$ & $\mathrm{df}$ & $\mathrm{p}$ (sig.) \\
\hline Group discussion & Male & 4.10 & .42 & .17 & 198 & .87 \\
& Female & 4.30 & .31 & .17 & 198 & .87 \\
Interpersonal & Male & 2.80 & .59 & 1.40 & 198 & .12 \\
\multirow{2}{*}{ Public speaking } & Female & 2.80 & .45 & 1.40 & 198 & .17 \\
\multirow{2}{*}{ Talking in meeting } & Male & 3.10 & .35 & .15 & 198 & .66 \\
& Female & 3.10 & .35 & .15 & 198 & .66 \\
& Male & 3.10 & .37 & .71 & 198 & .89 \\
& Female & 4.44 & .37 & .71 & 198 & .89 \\
\hline
\end{tabular}

Table 8 shows the comparison of male and female ESL teachers willingness to communicate (WTC) in English for all four constructs of communication. From Table 8, there is a slight difference of mean for construct 1 and 4 of communication: Group discussion and talking in meeting among male and female ESL teachers. However, when we examine the independent t-test for both construct 1 and $4, \mathrm{t}(198)=.17, \mathrm{P}>0.05$ and $t(198)=.71, P>0.05$. This means that there are no significant differences for the mean score for males and females in this sub-dimension of attitude. These results are aligned with Donovan and MacIntyre (2004) study, which reveals that there were no significant differences in WTC between male and female participants. Thus, it may be possible that both male and female ESL teachers have great self-efficacy and interest in using the English language to communicate. However, the relatively high mean score of female ESL teachers $(\mathrm{M}=4.44$ out of a 5.00-point scale) signifies that female ESL teachers, in general, are more willing to communicate in English in a meeting. This result may suggest that ESL female teachers have higher English language proficiency in general, and they are less anxious English language users compare to ESL male teachers. This finding lends support to what has been reported by Alavania and Alikhani
(2014) and others (e.g., Alemi, Tajeddin, \& Mesbah, 2013; Arshad et al., 2015; Oz, Demirezen, \& Pourfeiz, 2015) where females outperform males in their willingness to communicate in English.

With respect to comparing WTC in English and school locations, Table 9 presents the overall comparison of urban and rural ESL teachers' willingness to communicate in English.

The urban ESL teachers' mean score of 3.68 is higher than that of the rural peers, a mean score of 3.10. This shows that urban ESL teachers are more willing to communicate in English. For the case above, a t-test with a 2-tail probability was applied to find out whether there are overall differences between school locations and willingness to communicate in English. As is shown in Table 9, a p-value of $0.00(\alpha<0.01)$ indicates that the variance for willingness to communicate in English between the two groups, urban and rural, is not equal. As the $p=0.65>0.05$, we reject the null hypothesis and conclude that there are overall significant differences between willingness to communicate in English and school locations. In other words, urban ESL teachers had a higher level of willingness to communicate in English compared to rural ESL teachers. This may indicate that that the degree of exposure to the use of English language is higher among urban ESL teachers and as a result, they are 
more confident in using the English language regularly. In addition, urban ESL teachers' level of English language proficiency could also be a probable factor to their willingness to communicate (WTC) in English.

Table 9. T-test for comparing the overall willingness to communicate in English of urban and rural ESL teachers

Group Statistics

\begin{tabular}{llccccc}
\hline & School locations & Mean & Std. dev. & $\mathrm{t}$ & $\mathrm{df}$ & $\mathrm{p}$ (sig.) \\
\hline \multirow{2}{*}{ Willingness to communicate in English } & Urban & 3.68 & .24 & .32 & 198 & .00 \\
& Rural & 3.10 & .22 & .32 & 198 & .00 \\
\hline
\end{tabular}

To be more precise, I compared both urban and rural ESL teachers using t-tests with a p-value < 0.05 in terms of the four constructs of communication namely (i) group discussion, (ii) interpersonal, (iii) public speaking, and (iv) talking in meeting to find out whether the differences between school location and each construct were significant or not. Table 10 below shows the comparison of male and female ESL teachers willingness to communicate (WTC) in English for all four constructs of communication.

Table 10. T-test for comparing all 4 constructs of communication between urban and rural ESL teachers

\begin{tabular}{llccccc}
\hline Constructs of communication & School locations & Mean & Std. dev. & $\mathrm{t}$ & $\mathrm{df}$ & $\mathrm{p}$ (sig.) \\
\hline Group discussion & Urban & 4.13 & .48 & .31 & 198 & .00 \\
Interpersonal & Rural & 3.67 & .40 & .31 & 198 & .00 \\
& Urban & 3.18 & .34 & .29 & 198 & .00 \\
Public speaking & Rural & 2.97 & .29 & .29 & 198 & .00 \\
\multirow{3}{*}{ Talking in meeting } & Urban & 3.98 & .31 & .33 & 198 & .00 \\
& Rural & 3.82 & .25 & .33 & 198 & .00 \\
& Urban & 4.25 & .45 & .34 & 198 & .00 \\
& Rural & 3.18 & .34 & .34 & 198 & .00 \\
\hline
\end{tabular}

From Table 10, urban ESL teachers had the highest mean values $(\mathrm{M}=4.25)$ in the case of talking in the meeting, whereas rural ESL teachers showed the lowest mean values $(\mathrm{M}=2.97)$ for interpersonal communication. In addition, the result also indicates that all the four constructs of communication in terms school locations have a pvalue of $0.00(<0.05)$. Therefore, this means there are significant differences between ESL teachers' willingness to communicate in English in terms of school locations. This could be due to the different environments between urban and rural where most urban ESL teachers feel the need to communicate in English daily. As a result, they habitually converse in English and became less anxious, more confident, and more willing to communicate (WTC) in English.

Understanding the findings in light of previous studies in other countries and Malaysia

Table 11 below present the results of past-year studies on a willingness to communicate (WTC) in Asia and American context.

Table 11. Results of past-year studies on willingness to communicate (WTC)

\begin{tabular}{lcccc}
\hline Sub-constructs of communication & USA 1992 & Hong Kong 1996 & Korea 2011 & Current study 2017 \\
\hline Overall WTC & 65.6 & 44.7 & 49.2 & 67.8 \\
Group discussion & 70.8 & 48.3 & 47.1 & 72.1 \\
Interpersonal & 76.2 & 42.2 & 61.7 & 56.3 \\
Public speaking & 54.2 & 45.9 & 41.2 & 65.1 \\
Talking in meeting & 59.7 & 42.2 & 46.8 & 76.1 \\
\hline
\end{tabular}

The comparison of current study results shows that Malaysian ESL teachers were the highest in their overall willingness to communicate in English compared to the other three countries - USA, Hong Kong, and Korea. Interestingly, Malaysian ESL teachers were the highest in their scores for willingness to communication in a group while the lowest were the Korean.

The current study also revealed that Malaysian ESL teachers were the highest scores for talking in the meeting and public speaking followed by the
USA and the other two Asian studies. From table 8, the results also show us that interpersonal communication was the lowest for Malaysian ESL teachers, while the highest were the results of the study conducted in the USA followed by Korea and Hong Kong.

Overall, the current study shows that Malaysian ESL teachers were the most willing to communicate in English and were the highest for willingness to communicate in the meeting. 


\section{CONCLUSION}

This study investigated Malaysia ESL teachers' willingness to communicate in English in terms of gender and school locations. In doing so, the four constructs of communication in WTC introduced by McCroskey and Bear (1985) namely group discussions, interpersonal, public, and talking in the meeting was applied in this study. The findings reveal that ESL teachers preferred to initiate communication in English during the meeting rather than in group or public. However, female ESL teachers were significantly different in their overall willingness to communicate as they were more willing to communicate in groups and public. These findings support previous studies (Alavania \& Alikhani, 2014; Alemi et al., 2013; Arshad et al., 2015; Oz et al., 2015) that suggest female teachers are less anxious English language users and have higher English language proficiency in general.

Although some studies (Alavania \& Alikhani, 2014; Arshad et al., 2015) have indicated that students' gender towards willingness to communicate provides inconsistent results, the significant differences in gender and school location among ESL teachers must be taken into consideration too. The researcher views the reasons behind this significance as one of the most important school-related factors influencing students' achievement, competencies, and skills. If this issue of low English communication proficiency and high expectations among ESL teachers and learners is not addressed in the educational setting, this incompetence will continue to receive nonessential consideration, development, and treatment. Fatimawati (2012) argue that when ESL teachers neglect the communication skills in English, they have failed to carry out their duties as ESL teachers and foresee as the results of the decline in English language policy in Malaysia.

Regarding ESL teachers' willingness to communicate (WTC) in English in terms of school locations, an important finding has emerged from this study. The finding reveals that urban ESL teachers were more willing to communicate in English with friends and individuals compared to rural ESL teachers. One of the implications is that, as the Blueprint Malaysian Education 2013-2025 have placed increasing emphasis on English communication and English as the basic communication channel, schools should encourage more ESL teachers to participate English-related activities and empower them by providing opportunities and professional development such as workshops/training that can scaffold them communicate in English away from stress caused by the curriculum based activities.

In light of future research, a study adopting the method of this present study can be carried out in a bigger scale by involving more ESL teachers or schools in Malaysia or other countries to ascertain willingness to communicate (WTC) in English among ESL teacher in L2 context. As discussed earlier, most of the relevant past studies focussed on determining the types, conceptualisation, impact of WTC construct, and its measurement or factors loadings of WTC in English (e.g., communication anxiety in English, perceived communication competence in English) among learners (e.g., high school learners, undergraduates, trainee teachers) willingness to communicate (WTC) in English in a school, department, or university (Peng, 2007; Wen \& Clement, 2003; Fahim \& Dhamotharan, 2016; Lahuerta, 2014; Mwalongo, 2016; Yashima, 2002; Yousef et al., 2013). Hence, there is a paucity of research that addresses the concept of willingness to communicate (WTC) in English specifically in the ESL teachers' context.

Finally, neither previous studies nor this study sufficiently addresses the relationship or effect between language proficiency and willingness to communicate (WTC). Hence, a future study may examine the relationship or effect between ESL teachers' willingness to communicate (WTC) in English and language proficiency. This may help produce more data which could serve as a platform for reflections for teachers, educators, and schools on how to promote a conducive environment for speaking English both in and outside the classroom, and how and what can be done to improve the speaking and communication proficiency for both teachers and learners at all levels of education.

\section{REFERENCES}

Alavania, P. \& Alikhani, M. A. (2014). Willingness to communicate reappraised in the light of emotional intelligence and gender differences. Procedia Social and Behavioral Sciences, 98, 143-152. doi.org/10.1016/j.sbspro.2014.03.400

Alemi, M., Tajeddin, Z., \& Mesbah, Z. (2013). Willingness to communicate in L2 English: Impact of learner variables. Journal of Research in Applied Linguistics, 4(1), 42-61.

Arshad, Z., Shahbaz, M., \& Al-Bashabsheh, A. M. B. (2015). Willingness to communicate in English: A gender-based study. International Journal of English and Education, 4(4), 311319.

Blueprint, Malaysia Education Blueprint 2013-2025. (2013). Ministry of Education, Malaysia.

Burgoon, J. K. (1976). The unwillingness to communicate scale: Development and validation. Communications Monographs, 43(1), 60-69.

Donovan, L. A., \& MacIntyre, P. D. (2004). Age and sex differences in willingness to communicate, communication apprehension, and self-perceived competence. Journal of Communication Research Reports, 21(4), 420427. doi.org/10.1080/08824090409360006 
Fahim, A., \& Dhamotharan, M. (2016). Willingness to communicate in English among trainee teachers in a Malaysian Private University. Journal of Social Sciences, 12(2), 105-112. doi:10.3844/jssp.2016.105.112

Fatimawati, I. A. B. (2012). A study on the relationship between Malaysian learners' selfconcept in academic writing and their engagement in one higher learning institution (Unpublished doctoral dissertation). Massey University, Palmerston North, New Zealand.

Fern, N. P., \& Jiar, Y. K. (2012). Preschool teachers' beliefs and practices on early literacy instruction. Seminar Kebangsaan Majlis Dekan Pendidikan IPTA.

Gardner, R. C., \& Lambert, W. C. (1972). Attitude and motivation in second language learning. Rowley, MA: Newbury House.

Gill, S. K. (2005). Language policy in Malaysia: Reversing direction. Language Policy, 4, 241260. doi: 10.1007/s10993-005-7859-9

Ghonsooly, B., Khajavy, G. H., \& Asadpour, S. F. (2012). Willingness to communicate in English among Iranian non-English major university students. Journal of Language and Social Psychology, 31(2), 197-211. doi: 10.5539/elt.v9n5p33

Kaiser, H. F. (1974). An index of factorial simplicity. Psychometrika, 39(1), 31-36.

Lahuerta, A. C. (2014). Factors affecting willingness to communicate in a Spanish university context. International Journal of English Studies, 14(2), 39-55. doi: http://dx.doi.org/10.6018/j.193611

MacIntyre, P. D., Dornyei, Z., Clement, R., ～\& Noels, K. A. (1998). Conceptualizing willingness to communicate in an L2: A situational model of L2 confidence and affiliation. The Modern Language Journal, 82(4), 545-562.

McCroskey, J. C. (1992). Reliability and validity of the willingness to communicate scale. Journal Communication Quarterly, 40(1), 16-25.

McCroskey, J. C. (2006). The role of culture in a communibiological approach to communication. Human Communication, 9, 31-35.

McCroskey, J. C., \& Bear, J. E. (1985). Willingness to communicate: The construct and its measurement. Proceedings of the Annual Meeting of the Speech Communication Association. Denver, CO.

McCroskey, J. C., \& Richmond, V. P. (1982). Communication apprehension and shyness: Conceptual and operational distinctions. Communication Studies, 33(3), 458-468.

Mortenson, C. D., Arnston, P. H., \& Lustig, M. (1977). The measurement of verbal predispositions: Scale development and application. Human Communication Research, 3(2), 146-158.
Mwalongo, L. J. (2016). The factors affecting willingness to communicate in the Chinese language - A case study of northeast normal university international students. European Journal of Foreign Language Teaching, 1(1), 21-30.

Oz, H., Demirezen, M., \& Pourfeiz, J. (2015). Willingness to communicate with EFL learners in the Turkish context. Learning and Individual Differences, 37, 269-275. doi.org/10.1016/j.lindif.2014.12.009

Pattapong, K. (2010). Willingness to communicate in a second language: A qualitative study of issues affecting Thai EFL learners from students' and teachers' points of view (Unpublished doctoral dissertation). University of Sydney, Australia.

Peng, J. (2007). Willingness to communicate in an L2 in the EFL classroom: Rich descriptions from the Chinese university students. Review of Applied Linguistics in China, 3. doi:10.1.1.561.3662

Priest, R. F., \& Sawyer, J. (1967). Proximity and peership: Bases of balance in interpersonal attraction. American Journal of Sociology, 72(6), 633-649.

Ransirini, D. S. (2006). Motivation patterns among Sri Lankan undergraduates: A social constructionist approach (Unpublished doctoral dissertation). University of Malaya, Malaysia.

Skehan, P. (1989). Individual differences in second language learning. London: Edward Arnold.

Weaver, C. (2005). Using the Rasch model to develop a measure of second language learners' willingness to communicate within a language classroom. Journal of Applied Measurement, 6(4), 396-415.

Wen, W. P., \& Clement, R. (2003). A Chinese conceptualization of willingness to communicate in ESL. Language Culture and Curriculum, 16(1), 18-38. doi.org/10.1080/07908310308666654

Woodrow, L. J. (2006). Anxiety and speaking English as a second language. RELC Journal, 37(3), 308-328. doi/pdf/10.1177/0033688206071315

Yashima, T. (2002). Willingness to communicate in a second language: The Japanese EFL context. The Modern Language Journal, 86(1), 54-66. doi: 10.1111/1540-4781.00136

Yashima, T., Zenuk-Nishide, L., \& Shimizu, K. (2004). The influence of attitude and effect on willingness to communicate and second language communication. Language Learning, 54(1), 119-152. doi: 10.1111/j.14679922.2004.00250.x

Yousef, R., Jamil. H., \& Razak, N. (2013). Willingness to communicate in English: A study of Malaysian pre-service English teachers. English Language Teaching, 6(9), 205-216. doi:10.5539/elt.v6n9p205 
Indonesian Journal of Applied Linguistics, Vol. 7 No. 3, January 20I8, pp. 594-603

Zheng, M., \& Zhou, Y. (2014). Influence of English teachers' classroom English onstudents' learning enthusiasm in junior high school. International
Journal of Humanities and Social Science, 4(6), 269275. 